This is the accepted for publication version of a paper. The final definite version of the paper has been published in Journal of Dental Research, Vol. 91, No. 10 (2012) p. 909-9013 by Sage Publications@, All rights reserved. (Access to the published version may require subscription)

\title{
Discovery!
}

\section{The Legacy of Cariologist Douglas Bratthall, an Inspired Scientist}

\section{Dan Ericson, ${ }^{1}$ Peter Carlsson, ${ }^{1}$ Yupin Songpaisan, ${ }^{2}$ and Richard P. Ellen ${ }^{3 *}$}

${ }^{1}$ Department of Cariology, Faculty of Odontology, Malmö University, SE 20506 Malmö, Sweden

${ }^{2}$ Visiting Professor, Education and Research Center for Global Oral Health Science, Niigata University Graduate School of Medical and Dental Sciences, 2-5274 Gakkocho-dori Chuo-ku, Niigata 951-8514, JAPAN

${ }^{3}$ Faculty of Dentistry, University of Toronto, 124 Edward Street, Toronto, Ontario, Canada M5G $1 \mathrm{G} 6$

KEY WORDS: Douglas Bratthall; cariology; Streptococcus mutans; caries epidemiology; WHO; international collaboration; legacy

\section{*Corresponding author}

Telephone: 416-322-0450

Fax: 416-979-4936

E-mail: richard.ellen@dentistry.utoronto.c 
Research investigators seek facts which help generate ideas that uncover truths. During our careers, we discover each other and promising trainees whom we help to become the superseding research generation. There are those who approach a career as an exotic journey into the unknown. Some have an uncanny knack for creative flexibility, for staying in tune (Carson, 2011), and for leaving lasting imprints despite leaps in technology.

One such time, mind, and global traveller was Douglas Bratthall, who graced the Journal of Dental Research $(J D R)$ with an upbeat narrative of his career path, his personal 'safari' (Bratthall, 1997). Through our journey of rediscovery, we identify where his era's burning issues led in the ensuing fifteen years, and how they were shaped by Bratthall's unique style of playful curiosity, thoughtful inquisitiveness, incisive scholarship, and energetic leadership: 1) research on the biology of dental caries; 2) translational research on caries risk; 3) mutans streptococci as a global caries risk factor; 4) knowledge translation for the international promotion of oral health.

\section{New directions, biology of dental caries}

Knowledge of microbial - host immunity interactions has contributed profoundly to the understanding of dental caries, one of the most globally common diseases. Intense interest in the cariogenic streptococcus, Streptococcus mutans, was re-emerging as Douglas Bratthall pursued his doctoral thesis. It laid the foundation for antigenic diversity among what was then considered a single bacterial species (Bratthall, 1970), now recognized as the multi-species mutans group of streptococci. During Bratthall's career and continuing today, the mutans streptococci have captured 'front of the pack' attention. Even with advanced technology, mutans streptococci are still detected at very high frequency among the bacterial taxa most closely associated with 
advanced dental caries and early lesions in children (Gross et al., 2010; Tanner et al., 2011b). Indeed, in the most recent comprehensive studies, the two taxa most closely associated with advanced caries were S. mutans and Scardovia wiggsiae (Tanner et al., 2011a,b). Bratthall's original serotypes a-e coincided rather well with the subsequent genotype classification that led to their separation into different species (Coykendall, 1974). Serotypes $\mathrm{f}, \mathrm{g}$, and $\mathrm{h}$ were added along the way. There has even been a new antigenic group added within the past few years, serotype $\mathrm{k}$, which is evidently associated with infective endocarditis (Nakano et al., 2010). We find it remarkable that Bratthall's thesis has endured in both accuracy and relevance for 40 years.

Bratthall and his trainees grasped the pivotal role of mutans streptococci, and through their clever design of new sampling methods and comparative studies, theirs was one of the groups that helped determine that caries risk coincided with the mutans streptococcal load (Kristoffersson et al., 1985; Salonen et al., 1990) and with maternal transmission of mutans streptococci to infants (Köhler et al., 1983). The latter finding led to a seminal intervention study that supported the concept that generational transmission of caries risk could be interrupted by dietary and antimicrobial strategies aimed at the reduction of mutans streptococci in maternal saliva. Notably, a recent follow-up of 11- and 15- year olds demonstrated that a focus on mothers could provide long-term caries-reduction benefits in their children (Köhler and Andrèen, 2010). According to lead author Birgitta Köhler (personal communication), Bratthall had a naive, playful side that balanced with his serious side, characteristics which she believes enabled him to discover new angles and approaches. Maternal - infant transmission is still a consistent finding, despite the strain-tracking technology having become much more sensitive (Redmo Emanuelsson et al., 2003; Lapirattanakul et al., 2008; Kishi et al., 2009; Baca et al., 2011). 
Salivary protein binding to bacteria was another path trod by Bratthall, whose rationale was that bound proteins could affect bacterial adherence to teeth. Göteborg dental student Dan Ericson (Bratthall's eventual successor as Professor of Cariology) was 'hijacked' to Lund University, Malmö, by the prospect of becoming a discoverer in his own right, and was persuaded by Bratthall to frequent the lab of Göran Kronvall, who used radio-immuno-assays to measure the binding of secretory proteins to bacteria. This led to joint supervision of Ericson's thesis on the interaction of salivary beta-2-microglobulin with S. mutans (Ericson et al., 1979). Like Bratthall's own doctoral experience, he hit numerous roadblocks. Yet, Ericson was given typically Bratthallian advice: "Nature doesn't try to cheat you; you just need to think differently."

The influence of host inheritance on S. mutans colonization was an idea that nagged Bratthall and his mentor, Bo Krasse, for years, particularly why maternal transfer of mutans streptococci was not detected in some cases or why various bacterial genotypes were found in one child. In 1980, Russell and coworkers reported that individuals with a certain HLA-DR profile were less prone to develop antibodies to mutans streptocooci (Russell et al., 1980). With Bratthall's encouragement, doctoral candidate Marie-Louise Wallengren and Dan Ericson led a series of studies which found that the diversity of HLA profiles among human subjects influences their salivary IgA response to mutans streptococci and may, therefore, affect colonization (Wallengren, 2004).

\section{Truly translational research on caries risk}

Launching an expedition into the unknown was always a topic in Bratthall's group. Among his favourite 'guided tours' was to apply new knowledge in a way that would suggest practical tools 
for clinicians. For example, could one assess caries risk in a practice setting and among populations far removed from a modern clinic? Bratthall approached this question by developing ingenious modifications of selective bacteriology media and sample collection methods that were previously limited to research and clinics in academic centers. He and his team introduced: 1) The StripMutans method for estimating mutans streptococcal counts in the field (Jensen and Bratthall, 1989); 2) Dentobuff Strip, an analogous approach for estimating salivary buffering capacity (Ericson and Bratthall, 1989); and 3) the Cariogram, a practical multivariate approach to analyze caries risk (Bratthall and Hänsel Petersson, 2005). The Cariogram evolved in Bratthall's imagination over a characteristically lengthy period of deep thought. Typical for cariology, its roots can be traced to the iconic three intersecting circles (host/teeth, bacteria, diet) introduced by Keyes and Jordan (1963). Eventually, a dynamic model took shape by adding an interactive component and a display in the shape of a pie chart. The Cariogram conveys a research-based approach to a clinical situation. The program urges users to seek why the status of factors that affect the balance of caries risk vary in an individual patient (Hänsel Petersson et al., 2002). Today, the Cariogram is used in numerous research activities world-wide (Fadel et al., 2011), and for contextualizing thrusts in dental education (Gonzalez and Okunseri, 2010).

\section{Global field-testing of mutans streptococci as a caries risk factor}

Having developed practical methods for enumerating mutans streptococci, Bratthall was eager to take a broader geographical view of their distribution relative to caries experience. Exotic places like Lake Chad, where many of the indigenous people were caries-free, had frequently occupied his mind (Bratthall, 1997); this led to a series of studies of the coincidence of mutans 
streptococci and dental caries in regions of the world that were off the beaten path of previous research. Bratthall was a supporter of the 'specific plaque hypothesis' articulated by Loesche (1979), and he did not expect to find much S. mutans among the largely caries-free people near Lake Chad. Unfortunately, current events denied access for a study there; yet his team tested their hypothesis in many other remote populations in Africa, Asia, and Europe (Carlsson et al., 1985; El Tayab et al., 1985; Bratthall et al. 1986; Maher et al., 1992). Truly inventive, Bratthall was occasionally pressed to find methodological adaptations due to unanticipated challenges in the field. For example, hungry ants threatened to skew the bacterial count data by eating the polysaccharide-rich colonies directly off the StripMutans paddles left to air-dry. Bratthall's Swedish-designed field solution: suspend them from a string, out of reach of 'ants and other bacteriophages' (his term).

During these international studies, Bratthall and his student Peter Carlsson established a lasting collaboration with Yupin Songpaisan, who was working as a Senior Dental Officer at the Intercountry Centre for Oral Health $(\mathrm{ICOH})$ in collaboration with WHO in Chiangmai, Thailand. They conducted an initial 3-day-field study to collect data on caries and mutans streptococci among northern Thailand hill tribes that had either very high or low caries prevalence. They started early morning, drove great distances over rugged terrain, and relied on their own cooking. Bratthall defied local notions about workers from western countries being unable to adapt to hot, dusty, difficult conditions. He also served as a role model of how a great scientist should focus to test hypotheses. He always had provocative questions at the ready, and challenged his hosts to think deeply.

The outcome of these rural 'safaris' differed from studies in urban centers like Bangkok (Bratthall et al., 1986), in that mutans streptococci were ubiquitous, regardless of the rural caries 
prevalence. This tended to undermine the specific hypothesis. The studies were a clear indication that caries among geographically diverse populations depended on a broader combination of factors. Yet, they did not lessen Bratthall's fascination with mutans streptococci; they helped spawn his personal rediscovery of the multifactorial nature of caries and more complex ideas for caries prevention.

Under Bratthall's guidance, new preventive programs developed in the countries where his quest to understand S. mutans distribution had led. The first was Poland, behind the former Iron Curtain, with logistics occasionally complicated by martial law. The very high caries prevalence was successfully diminished by hygiene and fluoride, a labor-intensive approach based squarely on Swedish research, provided by Poland's very first expanded duty nurses trained in the project (Carlsson et al., 1988).

Then Bratthall returned to Thailand and teamed up again with Songpaisan for a WHOsupported field project on using glass ionomer as an alternative fissure sealant. Bratthall proposed an additional test cell, a $0.5 \%$ HF solution applied to the occlusal surface, which would be simpler than a sealant. It was a large study of high risk children (aged 7-8, 12-13 years) at two primary schools in Bangkok, and designed to collect caries, StripMutans, and salivary buffering data at baseline and annually for two years. A significantly lower caries increment in the HF than control group was found for the younger age group. The level of mutans streptococci was significantly related to caries prevalence and increment, and the outcome of various treatments was associated with the level of mutans streptococci at baseline (Songpaisan et al., 1994, 1995).

Another innovative approach was the 'Affordable Toothpaste Project', which grew from one of Bratthall's assignments when working for the WHO under a special agreement with 
Malmö's dental faculty. According to Gennady Pakhomov, a key WHO collaborator (personal communication), Bratthall rationalized that fluoride-containing dentifrices would be efficacious in developing countries experiencing a rise in caries incidence, perhaps due to increased sugar consumption. He was well aware that toothpaste was often too costly for people in some countries to purchase. When WHO contacted major manufacturers, Colgate provided funds for a joint, 3-year community study to evaluate the clinical efficacy of a dentifrice stripped down to essential ingredients. Bratthall launched it in a remote area of Indonesia, the island of Borneo, much to his Swedish coworkers' delight. The dentifrice was effective (Adyatmaka et al., 1998), and WHO distributed over 20,000 copies of a report, in various languages, around the world. It stimulated the production of low cost fluoride dentifrices by several other manufacturers.

\section{Translating knowledge of cariology and international promotion of oral health}

Bratthall was influenced by his native west coast of Sweden. He was fascinated by all sizes of boats, and he piloted small aircraft as a young man. He even proposed marriage with his head literally in the clouds. He was one of a breed of individuals attracted to highly novel ideas. Like another Douglas whose mind travelled to exotic heights (Adams, 1979), he was quick to foresee the implications of the internet, especially for global education. Influenced by his son Lars, an emerging computer guru, Bratthall created a unique Cariology home-page early in the 1990s. He targeted not only scholars in his field, but anyone, anywhere who may be interested in searching the subject. Under the leadership of David Barmes, the WHO had recently created its Global Oral Data Bank, and decided to establish an internet site for its Country/Area Profile Program database. It chose the WHO Collaborative Centre in Malmö, which Bratthall initiated and sustained until retirement (now co-directed by Jayanthi Stenswärd and Peter Carlsson). 
Bratthall's innovative Cariogram (Hänsel Petersson et al., 2002; Bratthall and Hänsel Petersson, 2005), translated into several languages with his permission, including Thai by Matana Pruksapong, is still used in dental schools and public health services in Thailand and other Asian countries. The Indonesian version, translated by Irene Adyatmaka, has been developed further as a simulated model for identifying the high caries-risk group, and it is presently used nationwide in schools. According to Adyatmaka (personal communication), Bratthall's visits to Indonesia, 1993 and onward, did not just leave memories of a professor who dared to face the jungles of Borneo, but a warm-hearted educator who left a better understanding of science and who inspired a young Indonesian generation to bounce back from adversity.

Bratthall's studies in Africa (Carlsson et al., 1985; El Tayeb et al., 1985) and Asia (Bratthall et al., 1986, 1991, 1993, 1995; Maher et al., 1992; Shi et al., 1992; Songpaisan et al., 1994, 1995; Tayanin et al., 2002) represent a strong example of applying laboratory-based findings to population-based interventions... the translational cycle from evidence-based dentistry to practice-based dentistry. His insights about caries as a global problem brought us to a much better understanding of its etiology and prevention, especially early intervention, by identifying at-risk individuals and factors that promote its transmission (Bratthall, 2000).

\section{Conclusion, inspirational leadership with personal charm}

In his outstanding 'Discovery!' paper (Bratthall, 1997), Bratthall saluted an inspiring group of scientists whose tenacity and discoveries came together to make his own research feasible and productive. After reviewing his accomplishments, we conclude that Bratthall essentially defined his own key attribute by choosing the word 'inspiring'. Certainly, the manner in which he developed ideas and workable strategies for investigating problems was inspiring. Those who 
worked with him gained a great deal from his insight. Being a true mentor is tough; it requires a talent for figuring out how collaborators' and trainees' heads work. Bratthall had a penchant for identifying promising trainees, making first contact nonthreatening, and raising their interest to join his research enterprise. When guiding students, he always identified valuable features of their discoveries that were ripe for intense discussion. He had a playfully clever yet kind way to provoke thought. He rarely provided conclusive answers but always raised question upon question until he was satisfied that his trainees were thinking provocatively. He held that both he and the student learned from each other. His style created a collaborative atmosphere and inspired confidence.

Douglas Bratthall attracted others by being a voyager in his mind and in his science. He was a profound thinker who retained a youthful, impish way of convincing colleagues to sign up on his dreams. We were but four among his numerous local and international collaborators. He was a most inspirational character in our career development. We hope that our rediscovery of Douglas Bratthall's legacy inspires the readers of JDR.

\section{Acknowledgement}

The authors comprise three of Bratthall's former doctoral students and one visiting investigator (RPE). RPE expresses his deep gratitude to Douglas Bratthall (in memoriam) and Gunilla Tynelius Bratthall for organizing academic visits (late 1970s), a sabbatical year in Malmö (198081), and subsequent visits which led to over 30 years collaboration with colleagues at several Swedish universities and to continuing exchanges of culture, language, and friendship.

\section{References}


Adams, D (1979). The Hitchhiker's Guide to the Galaxy. Pan Books, London (UK).

Adyatmaka A, Sutopo U, Carlsson P, Bratthall D and Pakhomov G. (1998). School-based primary preventive programme for children. Affordable toothpaste as a component in primary oral health care. WHO, Geneva.

Baca B, Castillo AM, Liébana MJ, Castillo F, Martín-Platero A, Liébana J (2011). Horizontal transmission of streptococcus mutans in schoolchildren. Med Oral Patol Oral Cir Bucal Dec 6. [Epub ahead of print].

Bratthall, D (1970). Demonstration of five serological groups of streptococcal strains resembling Streptococcus mutans. Odont Revy 21:143-152.

Bratthall D (1991). Mutans streptococci -dental, oral and global aspects. J Indian Soc Pedod Prev Dent. 9:4-12.

Bratthall D (1997). A Streptococcus mutans safari. J Dent Res 76:1332-1336.

Bratthall D (2000). Introducing the Significant Caries Index together with a proposal for a new global oral health goal for 12-year-olds. Int Dent $J$ 50:378-384. 
Bratthall D (2005). Estimation of global DMFT for 12-year-olds in 2004. Int Dent J 55:370372.

Bratthall D, Hänsel Petersson G (2005). Cariogram--a multifactorial risk assessment model for a multifactorial disease. Community Dent Oral Epidemiol 33:256-264.

Bratthall D, Khim SP, Durward CS (1993). Dental caries and prevalence of mutans streptococci in a group of Cambodian children. Community Dent Oral Epidemiol 21:174-175.

Bratthall D, Serinirach R, Carlsson P, Lekfuangfu S (1986). Streptococcus mutans and dental caries in urban and rural schoolchildren in Thailand. Community Dent Oral Epidemiol ;14:274276.

Bratthall D, Serinirach R, Rapisuwon S, Kuratana M, Luangjarmekorn V, Luksila K, Chaipanich P (1995). A study into the prevention of fissure caries using an antimicrobial varnish. Int Dent $J$ $45: 245-254$.

Carlsson P, Olsson B, Bratthall D (1985). The relationship between the bacterium Streptococcus mutans in the saliva and dental caries in children in Mozambique. Arch Oral Biol 30:265-268.

Carlsson P, Struzycka I, Wierzbicka M, Iwanicka-Frankowska E, Bratthall D (1988). Effect of a preventive program on dental caries and mutans streptococci in Polish schoolchildren. Community Dent Oral Epidemiol 16:253-257. 
Carson SH (2011). Creativity and psychopathology: a shared vulnerability model. Can J Psychiatry 56:144-153

Coykendall AL (1974). Four types of Streptococcus mutans based on their genetic, antigenic, and biochemical characteristics. J Gen Microbiol 83:227-238.

El Tayeb Ibrahim Y, Bratthall D, Carlsson P (1985). Dental caries and Streptococcus mutans in Sudanese schoolchildren. Odontostomatol Trop ;8:77-80.

Ericson D, Bratthall D, Björck L, Myhre E, Kronvall G (1979). Interactions between human serum proteins and oral streptococci reveal occurrence of receptors for aggregated 32 microglobulin. Infect Immun 25:279-283.

Ericson D, Bratthall D (1989). Simplified method to estimate salivary buffer capacity. Scand J Dent Res 97:405-407.

Fadel HT, Al-Kindy KA, Mosalli M, Heijl L, Birkhed D (2011). Caries risk and periodontitis in patients with coronary artery disease. J Periodontol82:1295-1303.

Gonzalez CD, Okunseri C (2010). Senior dental students' experience with Cariogram in a pediatric dentistry clinic. J Dent Educ 74:123-129. 
Gross EL, Leys EJ, Gasparovich ER, Firestone ND, Schwartzbaum JA, Janies DA, Asnani K, Griffen AL (2010). Bacterial 16S sequence analysis of severe caries in young permanent teeth. J Clin Microbiol 48:4121-4128.

Hänsel Petersson G, Twetman S, Bratthall D (2002). Evaluation of a computer program for caries risk assessment in schoolchildren. Caries Res. 36:327-340.

Jensen B, Bratthall D (1989). A new method for the estimation of mutans streptococci in human saliva. J Dent Res 68:468-471.

Keyes PH, Jordan HV (1963). Factors influencing initiation, transmission, and inhibition of dental caries. pp 261-283 in Harris RJ, ed. Mechanisms of Hard Tissue Destruction. New York: Academic Press.

Kishi M, Abe A, Kishi K, Ohara-Nemoto Y, Kimura S, Yonemitsu M (2009). Relationship of quantitative salivary levels of Streptococcus mutans and S. sobrinus in mothers to caries status and colonization of mutans streptococci in plaque in their 2.5-year-old children. Community Dent Oral Epidemiol 37:241-249.

Köhler B, Bratthall D, Krasse B (1983). Preventive measures in mothers influence the establishment of the bacterium Streptococcus mutans in their infants. Arch Oral Biol 28:225231. 
Köhler B, Andréen I (2010). Mutans streptococci and caries prevalence in children after early maternal caries prevention: a follow-up at eleven and fifteen years of age. Caries Res 44:453458.

Kristoffersson K, Gröndahl HG, Bratthall D (1985). The more Streptococcus mutans, the more caries on approximal surfaces. J Dent Res 64:58-61.

Lapirattanakul J, Nakano K, Nomura R, Hamada S, Nakagawa I, Ooshima T (2008).

Demonstration of mother-to-child transmission of Streptococcus mutans using multilocus sequence typing. Caries Res 42:466-474.

Loesche WJ (1979). Clinical and microbiological aspects of chemotherapeutic agents used according to the specific plaque hypothesis. J Dent Res 58:2404-2412.

Maher R, Khan A, Rahimtoola S, Bratthall D (1992). Prevalence of mutans streptococci and dental caries in Pakistani children. J Pak Med Assoc 42:213-215.

Nakano K, Nomura R, Matsumoto M, Ooshima T (2010). Roles of oral bacteria in cardiovascular diseases - from molecular mechanisms to clinical cases: cell surface structures of novel serotype k Streptococcus mutans strains and their correlation to virulence. J Pharmacol Sci 113:120-125. 
Redmo Emanuelsson IM, Carlsson, P, Hamberg K, Bratthall D (2003). Tracing genotypes of mutans streptococci on tooth sites by random amplified polymorphic DNA (RAPD) analysis. Oral Microbiol Immunol18:24-29.

Russell MW, Bergmeier LA, Zanders ED, Lehner T (1980). Protein antigens of Streptococcus mutans: purification and properties of a double antigen and its protease-resistant component. Infect Immun 28: 486-493.

Salonen L, Allander L, Bratthall D, Hellden L (1990). Mutans streptococci, oral hygiene and caries in an adult Swedish population. J Dent Res 69:1469-1475.

Shi Y, Barmes D, Bratthall D, Leclercq MH (1992). WHO pathfinder caries survey in Beijing extended with data for prevalence of mutans streptococci. Int Dent J 42:31-36.

Songpaisan Y, Bratthall D, Phantumvanit P, Somridhivej Y (1995). Effects of glass ionomer cement, resin-based pit and fissure sealant and HF applications on occlusal caries in a developing country field trial. Community Dent Oral Epidemiol 23:25-29.

Songpaisan Y, Serinirach R, Kuvatanasuchati J, Bratthall D (1994). Mutans streptococci in a Thai population: relation to caries and changes in prevalence after application of fissure sealants. Caries Res 28:161-168. 
Tanner A, Kent RL jr, Holderson PL, Hughes CV, Loo CY, Kanasi E, Chalmers NI, Johansson I. (2011a). Microbiota of severe early childhood caries before and after therapy. J Dent Res 90:1298-1305.

Tanner A, Mathney JM, Kent RL, Chalmers NI, Hughes CV, Loo CY, Pradhan N, Kanasi E, Hwang J, Dahlan MA, Papadopolou E, Dewhirst FE (2011b). Cultivable anaerobic microbiota of severe early childhood caries. J Clin Microbiol 49:1464-1474.

Tayanin GL, Ramanathan J, Bratthall D (2002). Caries prevalence and some caries related factors for 12 year-old children from Vientiane and Luang Prabang provinces in Lao People's Democratic Republic. Odontostomatol Trop 25:19-26.

Wallengren ML (2004). HLA, salivary IgA and mutans streptococci - is there a relation? Swed Dent J Suppl 166:1-67. 